\title{
Evaluation of anticonvulsant effects of stem bark of Anogeissus latifolia (Roxb.) in mice
}

\author{
Vikas Chandra Sharma ${ }^{1,2^{*}}$, Atul Kaushik ${ }^{2}$ \\ ${ }^{1}$ Department of Pharmaceutical Sciences, IFTM University, Moradabad, India. \\ ${ }^{2}$ IPS College of Pharmacy, Gwalior, India.
}

\begin{tabular}{l}
\hline ARTICLE INFO \\
\hline Received on: $26 / 08 / 2018$ \\
Accepted on: 27/10/2018 \\
Available online: $30 / 11 / 2018$
\end{tabular}

\section{Key words:}

Dhava, seizures, phenytoin, ellagic acid, pentylenetetrazol.

\begin{abstract}
The stem bark of Anogeissus latifolia (Roxb.) (Family: Combretaceae) is used for the correction of various ailments in the traditional system of medicine. The present study aimed to investigate the anticonvulsant effect of the stem bark of A. latifolia (Roxb.). Anticonvulsant effect was assessed in maximal electroshock (MES) and pentylenetetrazol (PTZ)-induced convulsions in mice. Electric shock (50 mA for 0.2 seconds) was delivered with the help of corneal electrode to induce hind limb tonic extension, while pentylenetetrazol $(80 \mathrm{mg} / \mathrm{kg})$ was injected intraperitoneally to induce convulsion (clonic). Different concentrations of ethanolic extract of stem bark of A. latifolia (200, 400, and 600 $\mathrm{mg} / \mathrm{kg}$ ) were administered orally to mice. The ethanolic extract of stem bark of $A$. latifolia showed significant dosedependent protection against seizures in both MES and PTZ-induced convulsion models. These findings suggested that ethanolic extract of stem bark of A. latifolia exhibited anticonvulsant effect against MES and PTZ-induced convulsions in a dose-dependent manner which may be attributed to the presence of ellagic acid and other tannins.
\end{abstract}

\section{INTRODUCTION}

Epilepsy is a most common ancient neurological problem in the world. Nearly, 40-50 million people of a total population of the world are suffering from this neurological disorder (Kohling, 2002). Epilepsy is common in children below 7 years and after the age of 55 in adults. In India, dissemination of epilepsy was reported to be 5.5-7.9 per 1,000 persons which are around the 1/18th of the total population of India (Nag, 2000). Most common anticonvulsant drugs used for the treatments of epilepsy are phenytoin, valproate, carbamazepine, phenobarbital, primidone, and lamotrigine. The currently available drugs, if used judiciously and continuously, abolish seizures completely in $60 \%-80 \%$ of the patients and reduce their frequency in another $10 \%-20 \%$ of the patient. Despite their effectiveness, most of them produce many side effects like drowsiness, nausea, mental dullness, ataxia, teratogenesis, hematological changes, weight gain, paresthesia, hirsutism, congenital malformations,

\section{*Corresponding Author}

Vikas Chandra Sharma, Department of Pharmaceutical Sciences, IFTM University, Moradabad,India.E-mail: vikas.a.sharma08@gmail.com and hypertrophy of gums. For these reasons, there is a need for developments of new anticonvulsant drugs to improve epilepsy control and reduce its harmful effects (Gasior et al., 1997). In recent times, continuous efforts are being made with a focus on novel pharmacotherapy from natural sources (medicinal plants) for treatment of psychiatric diseases and neurological disorders due to their less toxic effects and good tolerability (Zhang, 2004). Anogeissus latifolia (Family: Combretaceae), commonly known as dhava, is one of the most important medicinal plant used in traditional systems of medicine. Plant is useful in urinary discharge, anemic conditions, piles (Kirtikar and Basu, 1975), fever (Nag et al., 2007), back pain, inflammation (Bala and Singh, 2013; 2016; Samar et al., 2015; Singh et al., 2016), dysuria, diarrhea, colic, cough, liver complaints, skin diseases, snake bite (Jain, 1991), and scorpion sting (Venkata Ratnam and Venkata Raju, 2008). The decoction of leaves is used in epileptic fits (Pawar and Patil, 2008), etc. Stem bark is also used in ethnomedicinal practices for the treatment of common cold and cough (Jain et al., 2010; Patil and Patil, 2005). The stem bark of the plant has antimicrobial, antiulcer (Govindrajan et al., 2006), antioxidant (Govindrajan et al., 2004b; Ramachandran et al., 2012), wound healing (Govindrajan et al., 2004a), hepatoprotective (Pradeep et al., 2009), hypolipidemic 
(Parvathi et al., 2009), antihyperlipidemic, and antidiabetic activities (Ramachandran et al., 2012; Saeed et al., 2012). The plant contains active phenolic phytoconstituent, ellagic acid, which is responsible for various pharmacological activities. Stem bark contains the phytoconstituents like tannin, $(+)$ leucocyanidin, ellagic acid (Reddy et al., 1965), 3, 4, 3'- tri-O-methylflavellagic acid-4'$\beta$-D-glucoside, 3, 3'-di- $O$-methyl ellagic acid-4'- $\beta$-D-Xyloside (Deshpande et al., 1976), $\beta$-sistosterol, steroid, triterpenoid, 3- $\beta$ hydroxy-28-acetytaraxaren (Rahman et al., 2007), $\beta$-penta- $O$ galloylated glucose, and gallotannin (Reddy et al., 1964).

Despite the ethnomedicinal use of the leaves of the A. latifolia in epileptic fits, no attempts were made to study the influence of neither leaves nor other aerial parts like stem bark on epilepsy. Hence, in the present study, attempts were made to study the effect of ethanolic extract of stem bark of A. latifolia on experimental models of epilepsy.

\section{MATERIALS AND METHODS}

\section{Authentification of plant materials}

The stem bark of $A$. latifolia was collected from Ghatigaon forest of Gwalior district. Plant material was authenticated by Mr. N. K. Pandey Research officer, Department of Botany in National Research Institute for Ayurveda-Siddha Human Resource Development, Gwalior. The voucher specimen no (5-4/10-11/NRIASHRD/Tech/Survey/1516) of plant materials was submitted to the Botany Department as a reference.

\section{Drug and chemicals}

All the standard drugs, diazepam, and phenytoin were procured as a gift sample from Royal Research Center, Navsari, Gujarat, while pentylenetetrazol was purchased from Sigma-Aldrich Chemicals, USA. All the chemical and reagents used for the experimental work were of analytical grade.

\section{Preparation of ethanolic extracts of stem bark of Anogeissus latifolia (ALEE)}

The stem bark of $A$. latifolia was dried in shade at room temperature $28^{\circ} \mathrm{C}-31^{\circ} \mathrm{C}$. Plant material ground to a coarse powder (40 mesh size) for extraction. Powdered plant material $500 \mathrm{~g}$ was extracted with ethanol at $50^{\circ} \mathrm{C}-60^{\circ} \mathrm{C}$ in Soxhlet apparatus for 24 hours. The extract was filtered through Whatman filter paper and dried in a rotary evaporator under vacuum for complete dryness. The crude extract was stored in desiccator and the percentage yield was calculated.

\section{Phytochemical analysis}

Different phytochemical test of ALEE was performed by standard methods (Khandelwal, 2002).

\section{High performance thin layer chromatography (HPTLC) analysis}

The extract was subjected to chromatography on TLC plates with a standard marker in order to characterize the sample for the presence of phytochemical markers (Stahl, 1969). Ellagic acid was chosen as a marker compound for ethanolic extract of stem bark of A latifolia. A CAMAG HPTLC system equipped with LINOMAT $\mathrm{V}$, an automatic TLC sampler, glass twin trough chamber $(20 \times 20$ $\mathrm{cm}$ ), scanner 3, and integrated Win CATS software was used for the analysis (CAMAG, Switzerland). TLC was performed on $20 \times$ $20 \mathrm{~cm}$ pre-coated and pre-activated silica gel $60 \mathrm{~F}_{254} 0.25 \mathrm{~mm}$ thick plates (E. Merck, Mumbai, India). The sample and marker were applied on the TLC plate as wide bands $(6 \mathrm{~mm})$ with an automatic applicator under a flow of nitrogen, $8 \mathrm{~mm}$ from the base and 10 $\mathrm{mm}$ from the wall, and the gap between two spots were $13.3 \mathrm{~mm}$ of the TLC plate. The development was carried out in a TLC chamber which was pre-saturated with mobile phase $(20 \mathrm{ml})$ for 30 minutes at room temperature $\left(25^{\circ} \mathrm{C} \pm 2^{\circ} \mathrm{C}\right.$ and $45 \%$ relative humidity). Mobile phase used for the development of bands consisted of chloroform:methanol:formic acid (8.5:1.5:0.4 v/v/v). The chromatogram run was up to $8 \mathrm{~cm}$. Subsequent to chromatographic development; TLC plates were dried in current air with the help of TLC plate dryer. The developed chromatogram was then observed in UV cabinet in $254 \mathrm{~nm}, 366 \mathrm{~nm}$, and after derivatization with detecting reagent vanillin-sulphuric acid.

\section{Animals}

Swiss albino mice of either sex (20-30 g) were procured from the Animal house of IPS College of Pharmacy Gwalior, Madhya Pradesh (India). The animals were kept in a standard plastic cage at controlled room temperature $22^{\circ} \mathrm{C} \pm 3{ }^{\circ} \mathrm{C}$ and relative humidity $50 \% \pm 5 \%$ with the 12 hours light and dark cycles with free access to water and food. The research protocol was conducted according to the guidelines of Committee for the Purpose of Control and Supervision of Experiments on Animals (CPCSEA) (Registration no. 1039/PO/Re/S/07/CPCSEA) after approval by Institutional Animal Ethical Committee (Approval no. IPS/B.Ph./ADM/2015/1783).

\section{Acute toxicity study}

Organization for Economic Cooperation and Development (OECD) 423 guideline was followed in the evaluation of acute oral toxicity study of ALEE (OECD, 2001). Mice $(n=3)$ were fasted overnight and orally administered ALEE in the limit dose of $2,000 \mathrm{mg} / \mathrm{kg}$. Animals were continuously screened for various autonomous and central nervous system functions, behavior changes, for 2 hours, after a period of 24 hours, 72 hours, and thereafter up to 14 days for any moribund condition or death. For the confirmation of the above result, the same study was conducted in another groups of three mice.

\section{Screening for anticonvulsant effects}

\section{Maximal electro shock (MES)-induced seizures}

MES model was used for the evaluation of the anticonvulsant effect of ALEE. Electro Convulsiometer (Model No EC-02) was used for delivering an electric shock (50 mA for 0.2 seconds) with the help of corneal electrode to induce hind limb tonic extension (HLTE) in mice (Kulkarni, 1999; Swinyard et al., 1952). ALEE was administered at the dose of 200, 400, and 600 $\mathrm{mg} / \mathrm{kg}$, orally while phenytoin ( $25 \mathrm{mg} / \mathrm{kg}$, intraperitoneally) was used as a standard drug. All the treatments were given 30 minutes before applying electric shock. Animals were divided into five groups, each group containing 10 mice.

Group I received normal saline solution $(10 \mathrm{ml} / \mathrm{kg}$, orally).

Group II received the standard drug, phenytoin (25 mg/kg, intraperitoneally). 
Group III, IV, and V received ALEE (200, 400, and 600 $\mathrm{mg} / \mathrm{kg}$, orally).

The total duration of HLTE, onset of convulsions, and incidence of mortality in all groups of animals were recorded. The animals which did not exhibit HLTE were considered protected.

\section{Pentylenetetrazol (PTZ)-induced seizures}

PTZ-induced seizures model was used for the evaluation of anticonvulsant effects of ALEE. PTZ ( $80 \mathrm{mg} / \mathrm{kg})$ was injected intraperitoneally to induce convulsion in mice. ALEE was administered at the dose of 200,400 , and $600 \mathrm{mg} / \mathrm{kg}$, orally while diazepam $(5 \mathrm{mg} / \mathrm{kg}$, intraperitoneally) was used as a standard drug. PTZ was administered 30 minutes after the drugs, and the onset and duration of convulsions (clonic) were observed (Kulkarni, 1999; Nisar et al., 2008). Animals were divided into five groups each group containing 10 mice.

Group I received normal saline solution $(10 \mathrm{ml} / \mathrm{kg}$, orally). intraperitoneally).

Group II received the standard drug, diazepam ( $5 \mathrm{mg} / \mathrm{kg}$,

Group III, IV, and V received ALEE (200, 400, and 600 $\mathrm{mg} / \mathrm{kg}$, orally).

\section{Statistical analysis}

The data were expressed as mean \pm SEM. Statistical significance was tested by one-way analysis of variance followed with Dunnett's multiple comparison tests using Graph pad prism software ver. 5.0. The difference in results was considered significant at $p<0.05$ in all cases.

\section{RESULTS}

\section{Preliminary phytochemical analysis}

Phytochemical screening of ALEE showed the presence of various phytoconstituents like alkaloids, tannins, carbohydrates, phenols, furanoids, quinones, steroids, saponins, flavonoids, and triterpenoids.

\section{HPTLC analysis}

HPTLC chromatogram of the standard ellagic acid solution showed an absorption band at $\mathrm{R}_{f}(0.38)$. ALEE also showed a similar peak of ellagic acid at $\mathrm{R}_{f}(0.38)$ in HPTLC chromatogram (Figs. 1 and 2) which indicates the presence of ellagic acid in ethanolic extract.

\section{Acute toxicity study}

Acute toxicity study of ALEE showed no lethality or any toxic reactions or moribund condition up to the last phase of the study. ALEE was safe up to a dose of $2,000 \mathrm{mg} / \mathrm{kg}$ and revealed normal activities with no death or moribund stage up to 14 days. The approximate lethal dose $50 \%\left(\mathrm{LD}_{50}\right)$ of orally administered ALEE was found to be more than $2,500 \mathrm{mg} / \mathrm{kg}$.

\section{Anticonvulsant effects}

MES-induced seizures

Treatment with ALEE (200, 400, and $600 \mathrm{mg} / \mathrm{kg}$ ) showed significant protection of animals in MES-induced convulsion exhibited protection against HLTE-induced electric shock with maximum protection (70\%) at $600 \mathrm{mg} / \mathrm{kg}$. ALEE treatment $(200,400$, and $600 \mathrm{mg} / \mathrm{kg})$ also showed significant $(p<0.05-p<0.001$, wherever applicable) reduction in latency
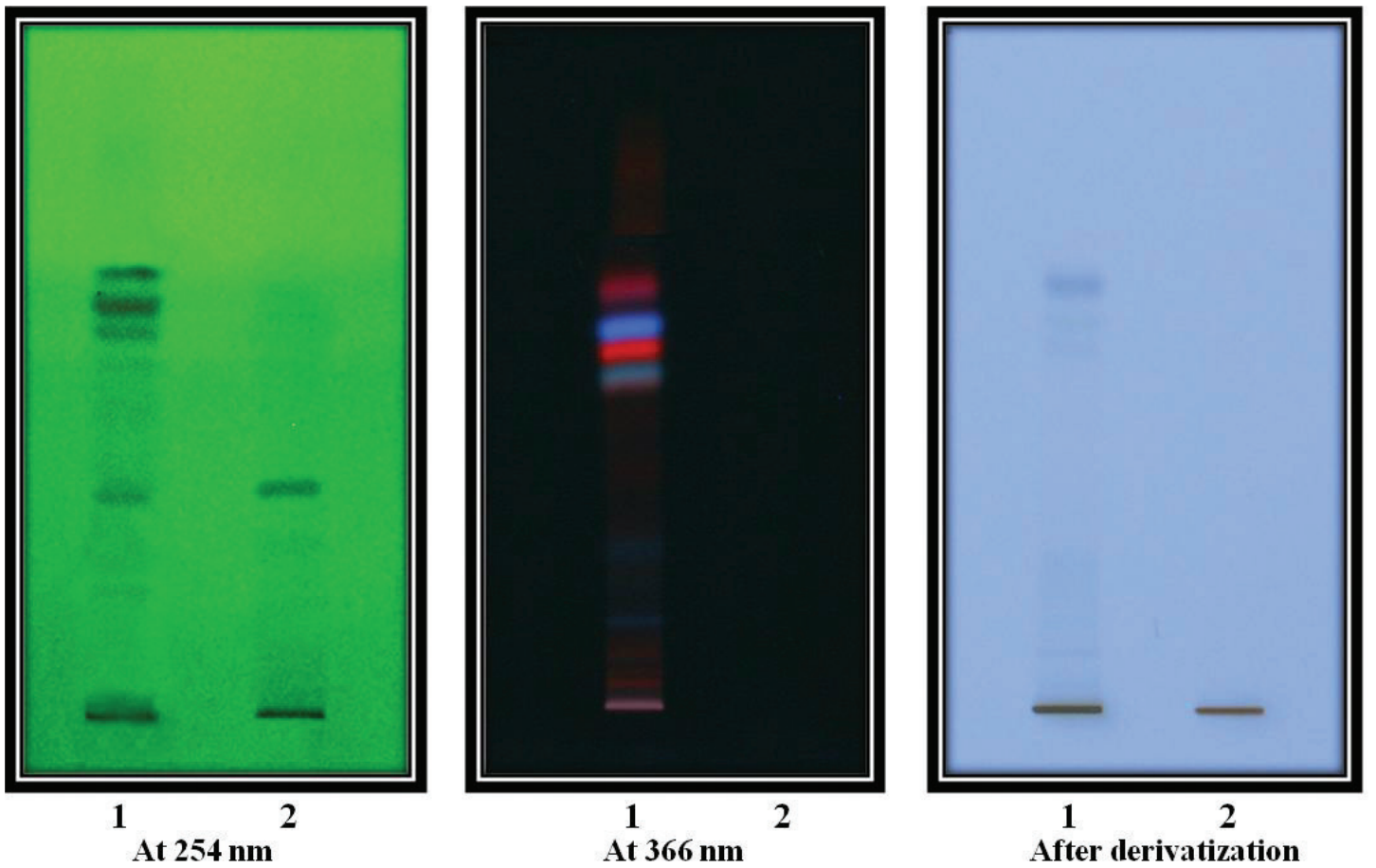

Figure 1. HPTLC profiles of ethanolic extract of stem bark of $A$. latifolia and ellagic acid at UV $254 \mathrm{~nm}, 366 \mathrm{~nm}$, and after derivatization with vanillin-sulphuric acid (Track 1: ethanolic extract and track 2: ellagic acid). 


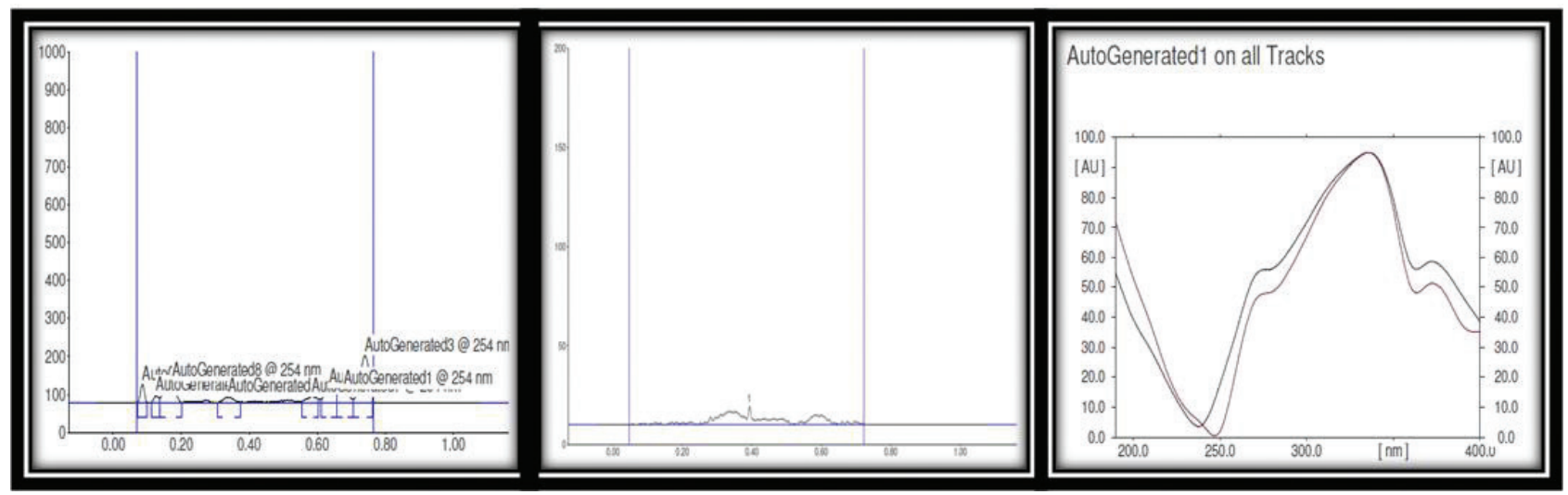

Figure 2. Densitogram and baseline analysis of ethanolic extract of stem bark of $A$. latifolia and ellagic acid.

time of convulsion when compared with control, wherein the maximum reduction in tonic seizures duration was exhibited with ALEE at $600 \mathrm{mg} / \mathrm{kg}$. Standard drug, phenytoin, also exhibited protection (100\%) against HLTE (Table 1).

\section{PTZ-induced seizures}

Treatment with ALEE (200, 400, and $600 \mathrm{mg} / \mathrm{kg}$ ) showed significant protection of animal in PTZ-induced convulsion with maximum protection $(80 \%)$ at $600 \mathrm{mg} / \mathrm{kg}$ dose. ALEE treatment $(200,400$, and $600 \mathrm{mg} / \mathrm{kg})$ also showed significant $(p<0.01-p<0.001$, wherever applicable) reduction in the latency time of seizures when compared with control, wherein the maximum reduction in clonic seizures duration was exhibited with ALEE at $600 \mathrm{mg} / \mathrm{kg}$. Standard drug, diazepam, also exhibited protection against clonic convulsion with $100 \%$ protection (Table 2).

\section{DISCUSSION}

TLC and HPTLC finger printing analysis of ALEE revealed the presence of prominent light brown spots of marker ellagic acid with $\mathrm{R}_{f}$ value at 0.38 (Figs. 1 and 2). Many other prominent compounds also showed absorbance band at $254 \mathrm{~nm}$, $366 \mathrm{~nm}$, and after derivatization with vanillin-sulphuric acid. HPTLC profile of ALEE confirms the presence of ellagic acid, an important phytoconstituents of ALEE.

The aim of the present study was to investigate the protective effects of ALEE on experimental models of convulsions. The MES-induced seizure model is used primarily as an indication for compounds which are effective in grand mal epilepsy, while

Table 1. MES-induced seizures in mice.

\begin{tabular}{lccc}
\hline Treatment & $\begin{array}{c}\text { Number } \\
\text { of animals } \\
\text { convulsed/No. } \\
\text { used }\end{array}$ & $\begin{array}{c}\text { Animals } \\
\text { protected } \\
\text { against } \\
\text { seizures (\%) }\end{array}$ & $\begin{array}{c}\text { Duration of HLTE (in } \\
\text { seconds) mean } \pm \text { SEM }\end{array}$ \\
\hline Control $(10 \mathrm{ml} / \mathrm{kg})$ & $10 / 10$ & 0 & $28.25 \pm 2.32$ \\
Phenytoin $(25 \mathrm{mg} / \mathrm{kg})$ & $0 / 10$ & 100 & 0.0 \\
ALEE $(200 \mathrm{mg} / \mathrm{kg})$ & $7 / 10$ & 30 & $21.45 \pm 2.11^{*}$ \\
ALEE $(400 \mathrm{mg} / \mathrm{kg})$ & $4 / 10$ & 60 & $13.53 \pm 1.41^{* * *}$ \\
ALEE $(600 \mathrm{mg} / \mathrm{kg})$ & $3 / 10$ & 70 & $7.21 \pm 0.78^{* * * *}$ \\
\hline
\end{tabular}

Results are expressed as mean $\pm \operatorname{SEM}(n=10) .{ }^{*} p<0.05 ;{ }^{* * * *} p<0.001$ compared with control. ALEE: Ethanolic extract of stem bark of A. latifolia. HLTE: hind limb tonic extension.
Table 2. PTZ-induced seizures in mice.

\begin{tabular}{lccc}
\hline Treatments & $\begin{array}{c}\text { Number } \\
\text { of animals } \\
\text { convulsed/No. } \\
\text { used }\end{array}$ & $\begin{array}{c}\text { Animals protected } \\
\text { against seizures } \\
(\%)\end{array}$ & $\begin{array}{c}\text { Duration of clonic } \\
\text { convulsion (in } \\
\text { seconds) } \\
\text { mean } \pm \text { SEM }\end{array}$ \\
\hline Control $(10 \mathrm{ml} / \mathrm{kg})$ & $10 / 10$ & 0 & $138.5 \pm 6.32$ \\
Diazepam $(5 \mathrm{mg} / \mathrm{kg})$ & $0 / 10$ & 100 & 0.0 \\
ALEE $(200 \mathrm{mg} / \mathrm{kg})$ & $6 / 10$ & 40 & $116.45 \pm 4.41^{* * *}$ \\
ALEE $(400 \mathrm{mg} / \mathrm{kg})$ & $3 / 10$ & 70 & $72.53 \pm 3.12^{* * *}$ \\
ALEE $(600 \mathrm{mg} / \mathrm{kg})$ & $2 / 10$ & 80 & $51.25 \pm 3.24^{* * * *}$ \\
\hline
\end{tabular}

Results are expressed as mean $\pm \operatorname{SEM}(n=10) .{ }^{* * *} p<0.01 ;{ }^{* * *} p<0.001$ compared with control. ALEE: Ethanolic extract of stem bark of A. latifolia.

the PTZ-induced seizure model represents a model for human generalized myoclonic and absence seizures (De Sarro et al., 2003; Löscher and Schmidt, 1988). The present study revealed that the ALEE attenuated both MES-induced tonic and PTZ-induced clonic seizures indicating that ALEE possesses anticonvulsant effects. In the MES and PTZ-induced convulsions, ALEE significantly reduced the latency and showed good protection in a dose-dependent manner. The effect was comparable with standard anticonvulsant drugs, phenytoin and diazepam, in their respective models of convulsions.

It is difficult to elucidate the exact mechanism responsible for the anticonvulsant action of ALEE. Most of the anticonvulsant drugs like phenytoin inhibit voltage-dependent $\mathrm{Na}+$ channels and prevent tonic extension in MES-induced convulsion (Browning, 1992; Liow et al., 2007; Rho and Sankar, 1999; Rogawski and Porter, 1990) while drugs like diazepam acts through binding with $\mathrm{GABA}_{\mathrm{A}}$ receptor complex and potentiate GABA (inhibitory neurotransmitter)-mediated inhibition by enhancing affinity of GABA neurotransmitter to its recognition sites in the GABA receptor complex. This ultimately increases the chloride channel opening frequency which leads to increase of the influx of chloride ion in the neurons, ensuing hyperpolarization. (Czapinski et al., 2005; Rang et al., 2012). Hence, it is possible that ALEE may have influence either on voltage-gated $\mathrm{Na}^{+}$channels or GABAergic neurotransmission.

Phytochemical analysis of ALEE revealed the presence of various phytoconstituents like carbohydrates, alkaloids, steroids, saponins, tannins, phenols, triterpenoids, quinones, furanoids, and flavonoids. It is difficult to ascribe the role of exact phytochemical 
in anticonvulsant action of ALEE. In previous studies, ellagic acid, a chief constituent present in ALEE showed good anticonvulsant effects against PTZ- and picrotoxin-induced convulsions. In the picrotoxin and PTZ-induced convulsions, ellagic acid showed good antiepileptic effects though the increase in the GABA levels in the brain (Dhingra and Jangra, 2014). Tannins like (-)-epigallocatechin; (-)-epigallocatechin-3-O-gallate and others have shown to exhibit anticonvulsant action (Kabuto et al., 1992; Yokoi et al., 1989). ALEE contains a higher concentration of ellagic acid and other tannin derivatives (gallotannins). Hence, it is possible that the observed anticonvulsant of ALEE may be due to the presence of an ellagic acid or other tannin derivatives. The study further needs the fractionation and isolation of various tannin derivatives present in the ALEE and their evaluation for anticonvulsant action, including the mechanisms involved.

\section{CONCLUSION}

The ethanolic extract of stem bark of $A$. latifolia showed anticonvulsant activity against both MES and PTZ-induced convulsions. The anticonvulsant effect of the extract may be attributed to the presence of ellagic acid and other tannins. Further studies are needed to elaborate molecular mechanism and identification of active phytoconstituents responsible for the anticonvulsant activity.

\section{ACKNOWLEDGMENTS}

The authors are very thankful to Dr. Manish Wanjari, Research Officer, Regional Ayurveda Research Institute for Drug Development, Gwalior, Mr. Bhagat Singh Jaiswal and Mr. Abhishek Pandey, Associate Professor, SOS in Pharmaceutical Sciences, Jiwaji University, Gwalior for their support.

\section{CONFLICT OF INTEREST}

Authors declare that they have no conflict of interest.

\section{REFERENCES}

Bala LD, Singh R. Traditional use of herbal medicines against Rheumatism by the tribals of Satna District (M.P.). Int J Sci Res, 2013; 4:1259-64.

Bala LD, Singh R. Ethnobotanical study of traditional medicinal plants used by Mawasi tribe of Chitrakoot region Distt. Satna (M.P.) India. Int J Biol Res, 2016; 1:13-5.

Browning R. The electro shock model, neuronal network and antiepileptic drugs. In: Faingold CL, Fromm GH (eds). Drugs for control of epilepsy: actions on neuronal networks in seizure disorders. CRC Press, Boca Raton, FL, 1992.

Czapinski P, Blaszczyk B, Czuczwar SJ. Mechanisms of action of antiepileptic drugs. Curr Top Med Chem, 2005; 5:3-14.

De Sarro G, Ferreri G, Gareri P, Russo E, De Sarro A, Gitto R, Chimirri A. Comparatie antionvulsant activityof some 2, 3-benzodiazepine derivaties in rodents. Pharmacol Biochem Behav, 2003; 74:595-602.

Deshpande VH, Patil AD, Rama Rao AV, Venkatraman K. 3, 3'-Di$O$-methyl ellagic acid-4'- $\beta$-D-Xyloside and 3, 4, 3'-tri- $O$-methylflavellagic acid-4'- $\beta$-Dglucoside from the Anogeissus latifolia bark. Indian J Chem, $1976 ; 14: 641-3$.

Dhingra D, Jangra A. Antiepileptic activity of ellagic acid, a naturally occurring polyphenolic compound, in mice. J Funct Foods, 2014; 10:364-9.

Gasior M, Carter RB, Goldberg SR, Witkin JM. Anticonvulsant and behavioral effects of neuroactive steroids alone and in conjunction with diazepam. J Pharmacol Exp Ther, 1997; 282:543-53.
Govindrajan R, Vijaykumar M, Rao CV, Shirwaikar A, Mehrotra S, Pushpangadan P. Healing potential of Anogeissus latifolia for dermal wounds in rats. Acta Pharm, 2004a; 54:331-8.

Govindrajan R, Vijaykumar M, Rao CV, Shirwaikar A, Rawat AKS, Mehrotra S, Pushpangadan P. Antioxidant potential of Anogenissus latifolia. Biol Pharm Bull, 2004b; 27:1266-9.

Govindrajan R, Vijaykumar M, Singh M, Rao CV, Shirwaikar A, Rawat AKS, Rawat P, Pushpangadan P. Antiulcer and antimicrobial activity of Anogeissus latifolia. J Ethnopharmacol, 2006; 106:57-61.

Jain SK. Dictionary of Indian folk medicine and ethnobotany. Deep publication, New Delhi, India, 1991.

Jain SP, Singh SC, Srivastava S, Singh J, Mishra NP, Prakash A. Hitherto unreported ethnomedicinal uses of plants of Betul district of Madhya Pradesh. Indian J Trad Knowl, 2010; 9:522-5.

Kabuto H, Yokoi I, Mori A. Monoamine metabolites, iron induced seizures, and the anticonvulsant effect of tannins. Neurochem Res, 1992; 17:585-90.

Khandelwal KR. Practical pharmacognosy techniques and experiments. 9th edition, Nirali Prakashan, New Delhi, India, 2002.

Kirtikar KR, Basu BD. Indian medicinal plants. Jayad Press, New Delhi, India, 1975.

Kohling R. Voltage-gated sodium channel in epilepsy. Epilepsia, 2002; 43:1278-95.

Kulkarni SK. Hand book of experimental pharmacology. 3rd edition, Vallabh Prakashan, New Delhi, India, 1999.

Liow K, Barkley GL, Pollard JR, Harden CL, Bazil CW. Position statement on the coverage of anticonvulsant drugs for the treatment of epilepsy. Neurology, 2007; 68:1249-50.

Löscher W, Schmidt D. Which animal models should be used in the search for new antiepileptic drugs? A proposal based on experimental and clinical considerations. Epilesy Res, 1988; 2:145-81.

Nag D. Gender and epilepsy: a Clinician's experience. Neurol Ind, 2000; 48:99-104.

Nag, A. Galav P, Kateva SS. Indigenous animal health practices from the Udaipur district, Rajasthan. Indian J Trad Knowl, 2007; 6:583-8.

Nisar M, Khan I, Simjee SU, Gilani AH, Obaidullah, Perveen H. Anticonvulsant, analgesic and antipyretic activities of Taxus wallichiana Zucc. J Ethnopharmacol, 2008; 116:490-4.

Organization for Economic Cooperation and Development (OECD). Guideline for the testing of chemicals, Revised draft guideline 423. Document on acute oral toxicity and acute toxicity class method, 2001 Available via http://www.oecd.org (Accessed 21 June 2013).

Parvathi KMM, Ramesh CK, Krishna V, Paramesha M, Kuppast IJ. Hypolipidemic activity of gum ghatti of Anogeissus latifolia. Pharmacogn Mag, 2009; 5:11-4.

Patil MV, Patil DA. Ethnomedicinal practices of Nasik district, Maharashtra. Indian J Trad Knowl, 2005; 4:287-90.

Pawar S, Patil DA. Ethnobotany of Jalgoan district, Maharashtra. Daya publishing House, New Delhi, India, 2008.

Pradeep HA, Khan S, Ravikumar K, Ahmed MF, Rao MS, Kiranmai M, Reddy DS, Ahamed SR, Ibrahim M. Hepatoprotective evaluation of Anogeissus latifolia: In vitro and in vivo studies. World J Gastroenterol, 2009; 15:4816-22.

Rahman MS, Rahman MZ, Ahad Uddin ABM, Rashid MA. Steriod and triterpenoid from Anogeissus latifolia. Dhaka Univ J Pharm Sci, 2007; 6:47-50

Ramachandran S, Naveen KR, Rajinikanth B, Akbar M, Rajasekaran A. Antidiabetic, antihyperlipidemic and in vivo antioxidant potential of aqueous extract of Anogeissus latifolia bark in type 2 diabetic rats. Asian Pac J Trop Dis, 2012; 2:S596-602.

Rang HP, Dale MM, Ritter JM, Moore PK. Pharmacology. 7th edition, Churchill and Livingstone, London, 2012.

Reddy KK, Rajadurai S, Nayudamma Y. Studies on Dhava (Anogeissus latifolia) Tannins: Part III-polyphenols of bark, sap-wood and heart wood of Dhava. Indian J Chem, 1965; 3:308-10. 
Reddy KK, Rajadurai S, Sastry KNS, Nayudamma Y. Studies on dhava tannins. I. Dhava tannins. The isolation and constitution of a gallotannin from dhava (Anogeissus latifolia). Aust J Chem, 1964; 17:238-45.

Rho JM, Sankar R. The pharmacologic basis of antiepileptic drug action. Epilepsia, 1999; 40:1471-83.

Rogawski MA, Porter RJ. Antiepiletic drugs: pharmacological mechanisms and clinical efficacy with consideration of promising developmental stage compounds. Pharmacol Rev, 1990; 42:223-86.

Saeed S, Mosa-Al-Reza H, Fatemeh AN, Saeideh D. Antihyperglycemic and antihyperlipidemic effects of guar gum on streptozotocin-induced diabetes in male rats. Pharmacogn Mag, 2012; 8:65-72.

Samar R, Shrivastava PN, Jain M. Ethnobotanical study of traditional medicinal plants used by tribe of Guna district, Madhya Pradesh, India. Int J Curr Microbiol App Sci, 2015; 4:466-71.

Singh D, Baghel US, Gautam A, Baghel DS, Yadav D, Malik J, Yadav R. The genus Anogeissus: A review on ethnopharmacology, phytochemistry and pharmacology. J Ethnopharmacol, 2016; 194:30-56.

Stahl I. Thin layer chromatography. A laboratory hand book. Springer-Verlag, Berlin, Germany, 1969.
Swinyard EA, Brown WC, Goodman LS. Comparative assays of antiepileptic drugs in mice and rats. J Pharmacol Exp Ther, 1952; 106:319-30.

Venkata Ratnam K, Venkata Raju RR. Folk remedies for insect bite from Gundlabrahmeswaram wild life sanctuary, Andra Pradesh. Indian J Trad Knowl, 2008; 7:436-7.

Yokoi I, Kabuto H, Akiyama K, Mori A, Ozaki M. Tannins inhibit the occurrence of epileptic focus induced by $\mathrm{FeCI}_{3}$, injection in rats Jpn J Psychiatry Neurol, 1989; 43:552-3.

Zhang ZJ. Therapeutic effects of herbal extracts and constituents in animal models of psychiatric disorders. Life Sci, 2004; 75:1659-99.

How to cite this article:

Sharma VC, Kaushik A. Evaluation of anticonvulsant effects of stem bark of Anogeissus latifolia (Roxb.) in mice. J App Pharm Sci, 2018; 8(11): 069-074. 